\title{
Improving Child Well-Being? Restructuring Child Welfare Programs in the Liberal Welfare States
}

\begin{abstract}
Maureen Baker ${ }^{1}$
Abstract

For over a century, the 'liberal' welfare states have shared ideas about social provision and faced similar socioeconomic and political pressures to restructure their social programs. This paper discusses some of the historic and current pressures on these states to develop and restructure child welfare services. I argue that international ideas about children's rights and 'best practices' have always influenced the development of these programs but current restructuring is more often shaped by concerns about public spending and the role of the state in family life. Despite the potential for governments in these 'rich' nations to enhance the wellbeing of children, unhealthy practices are permitted to continue.
\end{abstract}

\section{Introduction}

For over a century, the English-speaking countries or 'liberal' welfare states ${ }^{2}$ have legally protected children and provided minimal public support for families while permitting considerable family autonomy. Extensive lobbying by employers, unions, women’s groups and other social reformers has shaped the development and restructuring of these policies as some groups have tried to keep the state out of 'the family' while others have argued for greater intervention, such as protecting children from 'unreasonable force' in parental discipline (Bolderson \& Mabbett, 1991; Ursel, 1992; Gauthier, 1996). Since the 1970s, supra-national organizations such as the United Nations and the World Health Organisation have accelerated pressure on national governments to protect children's rights and ensure 'best practices' in health and social services. The 1960s and 1970s had been a period of rapid social change, with rising prosperity and educational levels, more women in the workforce, and greater emphasis on human and civil rights. Pressures to harmonize social policies increased in the 1980s as countries signed

1 Maureen Baker is a professor of Sociology at the University of Auckland in New Zealand. She is the author or editor of numerous books and scholarly articles relating mainly to family trends, women and work and comparative family policies. Her recent books include Restructuring Family Policies: Convergences and Divergences (University of Toronto Press, 2006) and Choices and Constraints in Family Life (Oxford University Press, 2007). Baker can be contacted at ma.baker@auckland.ac.nz

2 The concept of liberal welfare state has been used to describe systems of welfare funding and delivery that base social security largely on need and target benefits to low income and 'problem' families (Esping-Andersen 1990). Liberal welfare states usually include Canada, the United States, the United Kingdom, Australia and New Zealand 
multilateral agreements, labour markets became international, and employers and policy makers promoted neo-liberal practices (Yeates, 2001; Baker, 2006). Despite this pressure, public support for children and families still varies considerably by country and 'welfare regime'.

This paper provides a historical overview of the development and restructuring of child welfare programs in the 'liberal' welfare states (defined below), drawing on comparative and national studies of child protection and substitute care. I show that as early as the $19^{\text {th }}$ century, child welfare activists successfully lobbied for child protection legislation and residential institutions but major improvements to children's rights and child welfare practices were implemented during the welfare state expansionist years of the 1960s and early 1970s with pressure from international organisations and national interest groups. When social workers became more professionalized, they joined with 'social democratic' activists to persuade governments to restructure child welfare systems according to international standards of human rights and best practices. In recent years, however, business and financial interests have encouraged politicians to restructure social programs according to neo-liberal principles. While governments have retained some of the discourse of children's rights, I argue that they have not implemented the necessary reforms to improve children's outcomes.

\section{Welfare Regimes and Restructuring}

Numerous researchers have compared the development and restructuring of national social provision, including Esping-Andersen (1990) who categorised Western welfare regimes as

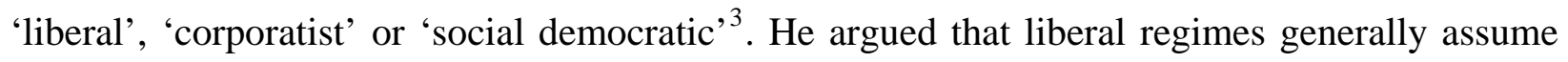
that individual earners are responsible for their own well-being, that the state should intervene only when households cannot cope, and that minimal benefits should be targeted to low-income households with few assets. In contrast, social democratic regimes focus on universal social services and the prevention of inequality, while corporatist regimes typically pay generous income support to members of social insurance programs developed jointly by employers, trade unions and governments. Esping-Andersen argued that welfare regimes were historically shaped by struggles among competing interest groups aligned with particular political parties. Despite

3 Esping-Andersen's classification was based on employment-related programs rather than family policies. 
changes in national governments over the years, these systems of social provision remain relatively consistent in their basic assumptions about why people need assistance, which delivering mechanisms are effective, and the best ways to fund social programs.

Many scholars have disputed the inclusion of particular countries in Esping-Andersen's scheme, including Castles (1985) who argued that Australia and New Zealand should not be placed in the same category as Canada, the United States and the United Kingdom. Nevertheless, other scholars have argued that the 'liberal' states share a number of family policy similarities that have persisted over time (Gauthier 1996; O’Connor, Orloff \& Shaver 2001, Baker 2006). I use the concept of the 'liberal welfare state' in this article to discuss child welfare reforms because these countries share the same legal system, language, cultural background ${ }^{4}$ and ideas behind social provision. By policy restructuring, I am referring to deliberate changes to legislation or policy directives that alter eligibility, subsidies, state support, or the departments or agencies implementing the programs. Before family-related policies are created or reformed, politicians must be persuaded that they fit with prevailing ideas about 'the family', do not conflict with powerful interests, and are consistent with budgets and existing social programs (Baker, 2006). By family policy, I mean official decisions to implement certain state-sponsored social programs, services, regulations and laws relating to families. I focus on child welfare programs in this article but family policies might also relate to reproductive health, income support, enforcing caring or support obligations among family members, or enabling the integration of earning and caring. I also acknowledge that family services are increasingly contracted out to non-government organizations or commercial ventures, under neo-liberal pressures to reduce the size and expenditures of government. However, these organizations are usually regulated by the state.

By 'neo-liberal pressures', I refer to arguments that the Keynesian welfare state ${ }^{5}$ is no longer affordable but also involved unwarranted state interference that encouraged 'welfare

4 Except Canada's province of Quebec which uses civil law and the French language and culture

5 The post-World War 2 welfare state, introduced by John Maynard Keynes, was characterized by deficit financing, state programs to support the growth of public sector jobs, and income support programs to cover lost earnings in times of unemployment, sickness and disability (McGilly, 1998: 13). 
dependency' and prevented individuals from organising their own affairs. Neo-liberals often accept the idea that state income support is needed for unemployed people in absolute need but usually argue that it should be transitional and time-limited. Instead of maintaining 'expensive' public programs, they recommend that the state should de-regulate the labour market, become less involved in economic activities and reduce taxes, suggesting that this would increase national productivity, employment rates and family well-being (Jones, 1997). Neo-liberals also believe that jobs are the best income security and that some social services could be provided more effectively by the private sector.

Numerous scholars have countered these statements by arguing that opening up the economy ('economic globalization') curtails the policy autonomy of national governments in employment and economic growth, but also worsens wages and working conditions, increasing the gap between the rich and the poor. They also argue that ideologies stemming from neoliberalism and globalization (including the prioritization of deficit and debt reduction, lowering taxation, and legitimizing inequality of rewards) encourage governments to reduce social spending and diminish the generosity of social programs (Mishra, 1999; Kelsey, 1995; Brodie, 1996; Kingfisher, 2002). Yeates (2001) adds that the pace, timing and impact of 'globalization' are not inevitable but rather are influenced by political agency, conflict and struggle.

In this paper, I show that both international and national pressures have always been placed on governments, presenting numerous policy options to every social 'problem'. I argue that throughout the history of child welfare, the liberal states have chosen some options over others but have not always promoted cost-effective services, best practices or healthy outcomes for families. Instead, family-related programs represent the outcome of compromises among interest groups about public spending, parental responsibilities and the role of the state. I argue that recent child welfare reforms retain some of the discourse reminiscent of the 1970s but this is combined with neo-liberal principles that became prominent after the 1980s. The coexistence of these two agendas provides contradictory programs and promotes poor outcomes for children. 


\section{Background: Early State Interventions in Family Life}

In the 18th century, children were regarded as chattels under English common law but parents were still required to maintain, protect and educate them (Bala \& Clarke, 1981: 2-4). By the 1880s, the lack of parental supervision became a political concern when truant and delinquent children increased in industrializing cities while their parents and guardians struggled to earn a living. Social reform groups comprised largely of maternal feminists ${ }^{6}$ urged governments to create legislation to protect these children but also to safeguard the public from delinquent behaviour (Baker, 1995).

Early child welfare laws were legislated in Australia (Victoria) in 1864 and in New Zealand (Otago) in 1867 (Matthews \& Matthews, 1998: 61). These laws typically allowed local governments to administer the care and custody of neglected and orphaned children, and encouraged the development of industrial and reformatory schools to house them and teach them work habits and Christian morals. The first private Children's Aid Society was established in United States in the 1870s but similar groups were later set up in Canada (Bala \& Clarke, 1981). In Ontario, maternal feminists persuaded the legislature to enact the Children's Protection Act in 1893 to mandate this Society to remove abused or problem children from parents and become their legal guardians. The development of child protection legislation demonstrated growing state concern for children's wellbeing but also acknowledged that parents no longer held sole authority over their children.

Religious and humanitarian-based charities continued to provide social services, sometimes with state subsidies (Swift, 1995; Dalley, 1998). Private agencies sponsored children's homes but also brought poor, homeless and orphaned children from the overcrowded British cities to 'the colonies'. For example, the philanthropist Thomas Barnardo organized the emigration of over 25,000 British children to Canada between 1882 and 1915, believing that emigration offered these children better opportunities in healthier environments. However, child emigration generated considerable controversy: trade unions argued that it provided colonial families with cheap labour and child welfare advocates objected to the lack of informed parental

6 This term has been used for early groups of middle class women who emphasized the importance of 'maternal concerns' to the welfare state, including protecting children and women's reproductive capacity 
consent for emigration, the estranged families and child abuse problems within colonial foster families. Eventually the controversy stopped these migration projects (Baker, 2001).

At the international level, infant and child protection received considerable attention, including the adoption of the International Labor Organisation's convention on maternity protection in 1919 that recommended paid employment leave and nursing breaks for new mothers (Heitlinger, 1993), and the United Nations Declaration of the Rights of the Child in 1924 (Gauthier, 1996: 27). National governments were urged to improve maternal employment and child welfare practices as well as the material circumstances of families, and many complied, partly through concern about infant mortality and family decline. Colonial governments saw improvements to child and maternal health as a way of promoting reproduction, stable communities and national population growth.

Maternal feminists and other social reformers also persuaded policy makers that children's institutions failed to offer the love and stimulation children needed to grow into healthy adults (Swift, 1995). Around the 1920s, the Toronto Children's Aid Society started placing children in private foster homes so they could grow up in a family and possibly be adopted, but residential institutions also proved costly to run and the children presented disciplinary challenges for care workers. Consequently, children's homes gradually became less prevalent over the years (Bala and Clarke, 1981; Baker, 2001: 61).

Some early state support was also granted to all parents of young children, although these programs typically contained motives other than poverty reduction. For example, Australia introduced a universal maternity allowance in 1912 to assist parents with birth expenses but also to reduce infant mortality and increase the (white) birth rate (Bradbury, 1996). The Australian government began allowing tax deductions for dependent children in 1915 and later for dependent spouses in 1936, although Canada already permitted such deductions in 1918 to encourage marriage and childbearing but also to slow the demand for wage increases by trade unions (Ursel, 1992).

The 1930s Depression provided a strong impetus for the liberal states to improve social protection and family support, including unemployment benefits for male breadwinners and improved child benefits. National policy debates were often influenced by discussions and 
reforms in other liberal states, such as the influence of the 1942 British Beveridge Report on Canadian social policy (Baker, 1995: 11). Population losses from the Second World War also led to widespread support for rebuilding families, although the liberal states continued to offer relatively ungenerous ${ }^{7}$ and stigmatized support for the male-breadwinner/female caregiver model of family.

Income support programs had been developed in the early $20^{\text {th }}$ century, focusing first on 'deserving' widows, as Table 1 indicates. These cash benefits enabled widows to raise their children at home rather than leaving them with relatives or in charitable institutions while they sought employment or remarriage (Baker \& Tippin, 1999). For years, women’s groups had pressed for mothers' pensions but most liberal states introduced tax relief for male breadwinners as well as universal child allowances in the 1940s (also shown in Table 1).

7 Ungenerous relative to benefits later provided in the 1970s by social democratic countries. 


\begin{tabular}{|c|c|c|c|c|}
\hline Country & Family Income Support & Child Allowances & Widows Pension & Benefit for Lone Mothers \\
\hline Australia & $\begin{array}{l}\text { 1944-1991 Unemployment } \\
\text { Assistance (federal \& means- } \\
\text { tested) } \\
\text { 1991: Job Search Allowance } \\
\text { and NEWSTART } \\
\text { 1993: Basic Family Payment } \\
\text { replaced Family Allowance; } \\
\text { 1994: Partner Allowance and } \\
\text { Home Child Care Allowance; } \\
\text { 1995: Above payments } \\
\text { combined to form Parenting } \\
\text { Allowance } \\
\text { 1998: Parenting Payment } \\
\text { (single and partnered) both } \\
\text { means-tested } \\
\text { 2000: Partnered Benefit became } \\
\text { Family Tax Benefit (means- } \\
\text { tested) }\end{array}$ & $\begin{array}{l}\text { - } 1941 \text { for families with two (2) or more } \\
\text { children } \\
\text { - } 1947 \text { made universal } \\
\text { - } \quad \text { 1987- targeted to middle- and lower- } \\
\text { income families } \\
\text { - } 1987-93 \text { Family Allowance } \\
\text { Supplement added for low-income } \\
\text { families } \\
\text { - } 1993 \text { - Additional Family Payment } \\
\text { replaced Family Allowance } \\
\text { Supplement }\end{array}$ & $\begin{array}{l}\text { - } 1942 \text { means- } \\
\text { tested } \\
\text { - } 1989 \text { became } \\
\text { part of Sole } \\
\text { Parent Pension }\end{array}$ & $\begin{array}{ll}\text { - } & 1973 \text { Sole Parent Pension - } \\
\text { until youngest child is } 18 \text { yrs } \\
\text { (means-tested) } \\
\text { - } \quad 1988 \text { Child Support Scheme } \\
\text { - } \quad \text { SP89 JET scheme } \\
\text { \& renamed Sole Parent } \\
\text { Benefit - 1995 converted to } \\
\text { Parenting Allowance - } 1998 \\
\text { converted to Parenting } \\
\text { Payment (single) } \\
\text { 2003: lone parents asked to } \\
\text { attend job-related interview } \\
\text { once a year, and to seek at } \\
\text { least six (6) hours of paid } \\
\text { work per week when } \\
\text { youngest child reaches 12 } \\
\text { years of age (down from 16) }\end{array}$ \\
\hline Canada & 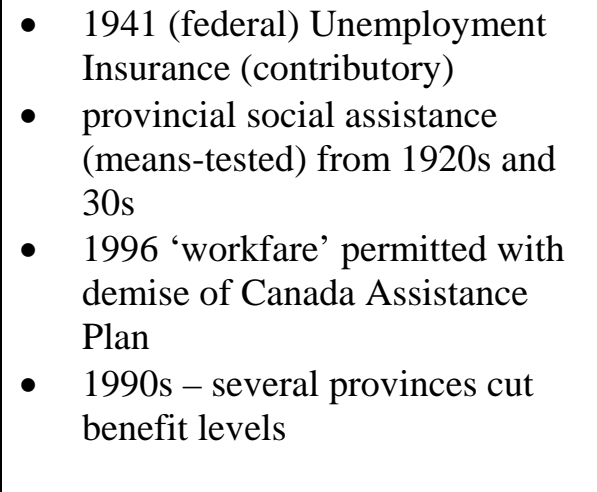 & $\begin{array}{l}\text { - } 1945-93 \text { universal } \\
\text { - } 1993 \text { converted to income-tested tax } \\
\text { credit (Child Tax Benefit) } \\
\text { - } \text { Beginning 1993, CTB contains a } \\
\text { working income supplement (WIS) } \\
\text { - } 1997, \text { WIS increased and paid per } \\
\text { child } \\
\text { - } 1998 \text { CTB and WIS combined to } \\
\text { create the Canada Child Tax Benefit } \\
\text { (1st child receives more money than } \\
\text { others) }\end{array}$ & $\begin{array}{l}\text { - Varies by } \\
\text { province but } \\
1920 \text { in } \\
\text { Ontario and } \\
\text { British } \\
\text { Columbia } \\
\text { 1966 Canada } \\
\text { Pension Plan } \\
\text { includes } \\
\text { survivors' } \\
\text { benefit }\end{array}$ & $\begin{array}{l}\text { - No federal benefit } \\
\text { - Provinces provide social assistance to } \\
\text { all low-income individuals and } \\
\text { families (some pay lone mothers at } \\
\text { higher rate) }\end{array}$ \\
\hline
\end{tabular}




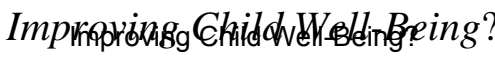

\begin{tabular}{|c|c|c|c|c|}
\hline Country & Family Income Support & Child Allowances & Widows Pension & Benefit for Lone Mothers \\
\hline New Zealand & $\begin{array}{l}\text { - } 1938 \text { unemployment and } \\
\text { sickness benefits (means-tested } \\
\text { on household income) } \\
\text { - } 1998 \text { Community Wage } \\
\text { (welfare to work program) }\end{array}$ & $\begin{array}{l}\text { - } 1926 \text { means-tested } \\
\text { - } 1946-91 \text { universal } \\
1991 \text { income-tested tax credit }\end{array}$ & $\begin{array}{l}1911 \text { means- } \\
\text { tested }\end{array}$ & $\begin{array}{l}\text { - } \quad \text { Deserted wives } 1936 \text { (means-tested) } \\
\text { - } 1973 \text { Domestic Purposes Benefit } \\
\text { means-tested } \\
\text { - } 1997 \text { National gov't tightened } \\
\text { eligibility rules changed from DPB } \\
\text { - } 20002 \text { changed back by labour gov't }\end{array}$ \\
\hline United Kingdom & $\begin{array}{l}\text { - } 1911 \text { unemployment insurance } \\
\text { - } 1934 \text { social assistance } \\
\text { - } 1988 \text { Income Support } \\
1988 \text { Family Credit (tops up } \\
\text { income of low-wage parents) }\end{array}$ & - 1945 to present - universal & - 1908 & - 1977 - 1997 one-parent benefit \\
\hline United States & $\begin{array}{l}\text { 1950-96 Aid to Families with } \\
\text { Dependent Children (means- } \\
\text { tested) } \\
\text { - } 1996 \text { Temporary Assistance for } \\
\text { Needy Families (means-tested) }\end{array}$ & $\begin{array}{l}\text { - } 1935-50 \text { Aid to Children (means- } \\
\text { tested) } \\
\text { - No federal child allowance }\end{array}$ & - Varies by state & $\begin{array}{l}\text { - 1950-96 - Aid to Families with } \\
\text { Dependent Children (means tested) } \\
\text { - } 1996 \text { temporary Assistance for Needy } \\
\text { Families (means-tested) }\end{array}$ \\
\hline
\end{tabular}

Source: Extracted from Baker 2006: 186-89 
These allowances were designed to assist with childrearing costs, acknowledge mother's caring work, supplement paternal wages and encourage citizens to procreate, thus providing future citizens, taxpayers and workers for the nation. These initiatives reflected the growing state interest in shaping family life, reducing poverty (often because it was associated with social unrest), and protecting employers from demands for higher wages (Ursel, 1992).

Before the 1960s, bearing a child outside marriage was considered a social disgrace but the dissemination of contraception and abortion were illegal in most liberal states (McLaren, 1999). Children born outside marriage were considered 'illegitimate' because they had no legal father and were not entitled to paternal support or inheritance. Without state income support or employment equity, mothers could seldom raise children without a male breadwinner and were often forced to abort illegally or permit their newborns to be adopted. However, post-World War Two prosperity enabled lobby groups to successfully press for major changes in the welfare state. International organisations such as the World Heath Organization publicized research on the importance of the mother-child bond (Gauthier 1996: 63) and the United Nations disseminated evidence of best practices in child welfare. Initiatives such as these were used to lobby governments to expand family services and income support.

\section{The Expansion of Welfare States}

By the 1960s, the liberal states began to administer more services previously offered by private agencies, such as regulating the existing children's homes and screening foster and adoptive parents. Some jurisdictions provided their own child protection programs while others mandated private agencies to offer these services. State interventions into families were managed by new guidelines such as the 'principle of least intrusion' and 'family preservation', in an effort to protect parental rights and children’s well-being (Krane, 2003).

As marriage breakdown and poverty in mother-led households began to increase in the late 1960s, public pressured mounted to improve income support for needy households and services for those experiencing family crises. The state began to support parents in poor or fraught households with cash benefits and visits from social workers. In 1973, Australia and New 
Zealand both offered all sole mothers the statutory right to public caring pensions if they had low incomes, few assets and no breadwinner (Baker \& Tippin, 1999). If parents abused their children or could not cope with them, the children were sent to unrelated foster homes with small government subsidies. Foster care was seen as a temporary solution permitting children to retain contact with their birth family while living in a more stable and disciplined home. The state also attempted to ensure that 'suitable' foster parents had stable marriages, were healthy and earned adequate incomes. Residential schools for indigenous children were closed during the 1970s and these children were seldom adopted by 'white' families as in the past. However, impoverished and indigenous children continued to be overrepresented among child welfare caseloads (Baker, 2001).

Before the 1970s, most adoptions involved permanently separating 'illegitimate' and abused or neglected children from their birth mothers with no future contact. However, psychologists and social workers began to argue that 'closed' adoptions were unsuitable solutions to birth outside marriage and parent/child conflict because they created negative psychological consequences for children and mothers. Child welfare advocates also argued that children should not be punished or stigmatized by their parents' activities or decisions, and most jurisdictions began to remove the concept of illegitimacy from legislation. Throughout the 1970s, mother-led households increased with higher rates of separation, divorce and births to unmarried mothers but state income support raised the material well-being of these families, acknowledging that raising children was socially useful work (O’Connor, Orloff \& Shaver, 1999).

Throughout the $20^{\text {th }}$ century, the state's approach to children evolved from emphasizing paternal authority, to granting the courts the right to make decisions on children's behalf in certain circumstances, to basing custody and support decisions on 'the best interests of the child', to viewing the child as a 'person' before the law (Bala \& Clark, 1981). This latter concept gained credence internationally when the United Nations accelerated its campaign to protect the rights and wellbeing of children by declaring 1979 the 'International Year of the Child'.

\section{Reinforcing Neo-liberal Agendas in Child Welfare}

While United Nations promoted children's rights throughout the 1980s, governments and the 
business sector became more concerned about the rising costs of social programs. Over the next two decades, entitlement to income support was curbed and more sole mothers were encouraged to raise their children on earned incomes with 'welfare' as the last resort or a supplement to wages (Baker \& Tippin, 1999). Especially in the United States, the duration of benefits was curtailed as governments developed 'workfare' programs and found new ways to establish paternity and enforce child support from non-resident fathers (Bashevkin, 1998). Income support was withheld from mothers who refused to identify the child's father as well as those whose youngest child was in school. The liberal states began encouraging extended family members, including grandparents, to provide substitute care for children when parents could no longer manage, as foster parents became harder to find with increasing maternal employment and rising childrearing costs (Connolly, 2003). States also began 'family group conferencing' to re-engage family members in disciplinary practices and encourage them to accept more responsibility for their children's behaviour.

Child maltreatment continued to be a public concern in all of the liberal welfare states. Authorities initially focused on physical abuse and neglect but attention also turned to sexual abuse when 1980s research found that more adults had been victimized as children than previously acknowledged. Community leaders became especially concerned about sexual abuse by teachers and youth workers as well as parents and guardians, searching for ways to identify potential abusers and deal with perpetrators (Baker, 2006). However, incidents are seldom witnessed and reporting is often delayed.

The liberal states have provided basic income support and services for neglected and abused children for years. However, they have recently reduced eligibility for income support and contracted out more services with fewer state resources. For example, the liberal states now encourage extended families rather than foster parents to care for abused or neglected children. 'Kin care' now accounts for over 24 per cent of substitute care arrangements in Australia (Hunt, 2003), over 31 per cent in the United States (Clark, 1995), and 32 per cent in New Zealand (Statistics NZ, 2002). This practice is justified by 'the best interests of the child' and 'family preservation' but kin carers tend to receive less state support than non-related caregivers. For this 
reason, the practice has also been seen as a form of neo-liberal restructuring to save public resources (Connolly, 2003).

One concern with kin care is that standards are less rigorously applied and carers are approved who would be unacceptable foster parents because of their low income, older age, single parent status, poor health, parenting problems or substandard accommodation (Hunt, 2003). In addition, children are more likely to continue living in poverty. Kin care remains less contentious because it keeps children within their community and cultural group but research comparing the outcomes of both kinds of care is underdeveloped and contradictory (Connolly, 2003). Nevertheless, governments continue to use kin care.

Unwanted births had been reduced through legalizing contraception and abortion, but more mothers have been raising children alone in recent decades. As separation and re-partnering increases, fewer adoptions involved unwanted infants or abused children and more include stepchildren of remarried partners. With fewer infants available for adoption, agencies continue to promote older children and those with behavioural problems or disabilities but many potential parents have found new options overseas. Governments have signed multilateral or bilateral agreements to govern international adoptions, stipulating that carers should be sought first within the child's extended family and culture, that children cannot be sold into adoption, and that their health must be assessed before and afterwards. Children cannot be adopted without informed parental consent (if available) and time for mothers to reconsider, and adoptive parents have to visit the child's country and be screened by agencies in both countries.

Countries hosting adoptions are now under international pressure to improve their child welfare services. More object to foreigners removing children, who are considered to be the nation's 'future resource', and have developed new regulations such as requiring potential parents to remain in the country for a lengthy period and to pay hefty 'administrative fees' (Baker, 2006). Consequently, international adoptions are becoming more legalistic and expensive. While some wealthy couples are paying large amounts to adopt foreign children, impoverished parents in the liberal states struggle to raise their children. 


\section{Focusing on 'Child Poverty' and Child Maltreatment}

In 1989, the Convention on the Rights of the Child became a binding international agreement and one of the problems identified for children in developed countries was growing up in impoverished households. The ceremonial launch in the United Nations helped to pressure political leaders to make policy commitments in their own parliaments. Conservative Prime Minister Brian Mulroney promised before the United Nations and Canada’s Parliament to seek to eliminate 'child poverty' by the year 2000, which prompted the creation of a lobby group called Campaign 2000 to ensure compliance (Baker, 1995: 68-9). Promises to reduce child poverty are periodically repeated when international and national studies indicate that poverty is flourishing. In 2000, the Blair Labour government in Britain promised to reduce child poverty by half in ten years and to eradicate it in twenty years (UNICEF, 2000: 5).

The United Nations Children's Fund (UNICEF), which regularly reports on children's well-being, recently noted that many 'rich' countries with resources to reduce poverty continue to permit children to live in households that are deleterious to their wellbeing (UNICEF, 2005). The 2005 report stated that three-quarters of OECD countries “appear to be losing ground against child poverty" (ibid: 14,17). Although anti-poverty discourse continues to be used by most political parties, child poverty rates $^{8}$ in liberal welfare states remain among the highest in the OECD, as Table 2 indicates.

8 Child poverty rates are often defined as the \% children living households with incomes less than $50 \%$ of the national median after taxes and transfers, and adjusted for family size. 
Table 2: Poverty Rates for Households with Children by Work Status of Parents, Late 1990s

\begin{tabular}{|c|c|c|c|c|c|}
\hline Country & Single Parent, No Worker & Single Parent, One Worker & Two Parents, No Worker & Two Parents, One Worker & Two Parents, Two Workers \\
\hline Australia & 58.7 & 11.7 & 43.3 & 5.4 & 3.3 \\
\hline Canada & 89.7 & 27.7 & 75.3 & 22.9 & 3.5 \\
\hline Denmark & 22.2 & 4.0 & 19.0 & 6.4 & 0.7 \\
\hline France & 61.7 & 9.6 & 37.9 & 6.3 & 1.6 \\
\hline Netherlands & 42.8 & 17.7 & 50.7 & 7.8 & 1.7 \\
\hline New Zealand & 87.6 & 21.3 & 43.3 & 14.5 & 4.1 \\
\hline Norway & 24.7 & 2.8 & 38.0 & 2.8 & 0.1 \\
\hline Sweden & 34.2 & 5.6 & 13.7 & 8.2 & 1.1 \\
\hline United Kingdom & 62.5 & 20.6 & 37.4 & 17.6 & 3.6 \\
\hline United States & 93.8 & 40.3 & 77.9 & 30.5 & 8.3 \\
\hline OECD (24 Countries) & 58.0 & 20.6 & 41.6 & 13.7 & 4.3 \\
\hline
\end{tabular}

Source: Extracted from OECD 2005: 57 
Considerable research shows that growing up in families with few material and cultural resources leads to multiple disadvantages throughout life (Lipman, Offord \& Boyle, 1994; Roberts, 1997; Hobcraft \& Kiernan, 2001). For example, children from low-income families have more than twice the incidence of chronic illness and disabilities as children living in nonpoor families, and are more likely to experience social impairments and psychiatric, emotional, hyperactivity and conduct disorders. Poor parents cannot always afford to purchase nutritious food, practice preventive healthcare, visit healthcare practitioners or find healthy homes in safe neighbourhoods. Poor people are also more likely to work in dangerous jobs, engage in risky lifestyles and violent behaviour, and children from these families are more likely to be subjected to maltreatment (UNICEF, 2003).

The UNICEF (2003) report suggests that various factors accumulate to augment the risk of child maltreatment. Parents who abuse alcohol and drugs and live in impoverished and violent homes are more likely to maltreat their children, which often leads to depression, anxiety and hostility in the children, as well as certain types of behaviour such as physical inactivity, smoking, alcoholism, drug abuse, risky sexual practices and suicide (UNICEF, 2003:19). There is growing concern across industrialized countries about the cost of child maltreatment to children, families, taxpayers and employers.

The report emphasizes that effective strategies include home visits to all families with young children by qualified health, education and social service staff, rather than targeting children assumed to be 'at risk' as is done in the liberal welfare states (UNICEF, 2003). The report argues that strategies must also address the economic circumstances of parents, as those living in impoverished and stressed conditions are statistically more likely to abuse their children (ibid: 21). Rates of child death from maltreatment, shown in Table 3, are relatively high in the liberal states, especially the United States. The trend in non-fatal child abuse is more difficult to establish because new reporting requirements and intervention programs have increased its visibility. 
Table 3: Child Maltreatment Deaths for Selected Countries

\begin{tabular}{|c|c|}
\hline Country & $\begin{array}{c}\text { Average \# of Deaths over Five (5) Year Period } \\
\text { Per 100,000 Children under 15 years }\end{array}$ \\
\hline Spain & 0.1 \\
\hline Italy & 0.2 \\
\hline Norway & 0.3 \\
\hline Sweden & 0.6 \\
\hline Australia & 0.8 \\
\hline Denmark & 0.8 \\
\hline United Kingdom & 0.9 \\
\hline Canada & 1.0 \\
\hline New Zealand & 1.3 \\
\hline United States & 2.4 \\
\hline
\end{tabular}

Source: Extracted from UNICEF 2003: 4. 
Research indicates that developing a culture of non-violence helps prevent and reduce child maltreatment (UNICEF, 2003). Consequently, some European countries (such as Sweden, Norway, Denmark and Austria) have banned the physical punishment of children, including by parents, and have funded educational campaigns about alternative discipline ${ }^{9}$. More jurisdictions also recognize the negative effects on children of witnessing male violence against their mothers and have amended child custody policies to consider the parent's history of domestic violence. However, cases governed by the multilateral Hague Convention, involving a parent's flight with children across international borders, primarily focus on returning children to their place of normal residence and give little credence to this history (Jaffe et al, 2003; Kaye, 1999). Many mothers who experience domestic violence fear for their children's safety, which is generally minimized in a complex and often hostile court system (Radford \& Hester, 2001).

International organizations such as United Nation's Children's Fund and the World Health Organisation reflect on the impact of changing family patterns, employment practices and entitlement to social benefits, attempting to motivate governments to compensate with familyrelated programs. Yet other international organizations such as the World Bank and the Organisation for Economic Cooperation and Development pressure governments to make neoliberal reforms that are beneficial to international capital and global trade (Yeates, 2003). Although international organizations have little power to force national governments to comply, the former organizations have experienced some successes in improving children rights over the years (Hantrais, 2004). They continue to argue that strategies to combat child maltreatment must address economic circumstances because parents living in impoverished, overcrowded and stressed conditions are more likely to be charged with abuse. Despite these efforts, income support in the liberal welfare states is not indexed to average wages, social housing remains under-funded (Bradshaw \& Finch, 2002), and resources to reduce family problems continue to be inadequate to meet reported incidences.

\section{Conclusion: Promoting Child Well-being?}

Although advocates of improved family services pressure governments to 'invest in children', business and financial groups demand lower taxes and de-regulation of labour markets.

9 New Zealand's controversial anti-smacking bill passed in May 2007. 
Governments are also lobbied by a variety of interest groups to respond to socio-demographic changes in families. For example, more marriages are now consensual, fertility rates have declined, families are smaller but less stable, and more children live in mother-led households and stepfamilies. Governments are lobbied to modify social programs to consider the social impact of these trends but groups vary in their definition of 'the problem' and their proposed solutions. UNICEF (2005) indicates that children's poverty tends to increase when more parents separate and the children live with their mother, when parental unemployment rises and when wages fall relative to living costs. They also note that poverty rises when governments cut social benefits and services or make them harder to obtain. At the same time, business groups pressure governments to limit eligibility for income support and keep benefits well below minimum wages in order to promote work incentives.

A major influence on recent restructuring has been associated with open markets and international trade, reflecting ideas and governing principles that give priority to economic markets in public policy. All industrialized countries are subjected to economic globalization and these neo-liberal pressures yet cross-national differences in social provision and welfare outcomes indicate that political agency is still possible under these conditions. Cross-national research shows that some governments continue to regulate wages and working conditions, develop tax systems and government transfers that stabilize and supplement earnings, keep poverty rates low for families with children, and offer proactive family services before problems become serious (Bradshaw \& Finch, 2002; OECD, 2005; UNICEF, 2005). Many of the social democratic states (such as Denmark and Sweden) continue to focus on the prevention of family poverty, disharmony and children’s behavioural problems.

In the liberal states, policy makers have expressed concern about children's welfare. These states continue to provide income support but levels in some jurisdictions are set well below the poverty line. In all of the liberal states, family services are targeted to 'at risk' families who have already come to the attention of the state. Governments have encouraged the reporting of suspected cases of child maltreatment but insufficient case workers are hired to protect these children even after a complaint has been filed. Safe houses for abused mothers and their children are supported by private donations as well as public money but are often staffed by volunteers and operate on the verge of closing due to lack of funds. Follow-up therapy and counselling may be necessary for the entire family but these services are often unaffordable for family members. 
All the liberal states except the United States have signed the Convention on the Rights of the Child and the United Nations continues to encourage all governments to legally protect children, provide a variety of family services, and ensure their effectiveness. Despite acknowledging the serious nature of child maltreatment, governments in the liberal welfare states have not always funded or supported the necessary programs. Most children in substitute care continue to come from socially disadvantaged families, often headed by mothers, but the care systems have been criticized for focusing more on 'bad mothering' than reducing poverty (Smith, 1991; Swift, 1995). Impoverished mothers in these countries are given professional advice on budgeting and childrearing but entitlement to 'welfare' is restricted and kept below the minimum wage. Governments have granted more legal rights to children and the state has assisted them in exercising these rights, but these reforms are relatively inexpensive.

Since the 1980s, business and financial interests have successfully pressured politicians to deregulate labour markets, reduce income taxes, tighten access to cash benefits and contract out many social services, using market principles for evaluation. These changes may save money for employers and governments but household incomes have become more polarized, giving some parents new opportunities to purchase private services while others cannot afford the necessities of life. The widening gap between the rich and the poor now requires new programs to deal with higher reports of malnutrition, certain contagious diseases, truancy, substance abuse, child maltreatment and delinquent behaviour - all aggravated by poverty and substandard living conditions (UNICEF, 2005).

State interventions into child well-being date back to the $19^{\text {th }}$ century but the liberal states accepted a more interventionist role in child and family welfare during the 1960s and 1970s. Now more politicians say that children are the nation's 'future resource' and talk about the importance of family harmony and well-being. At the same time, they encourage low-wage work, reliance on market earnings and private services with lower levels of public funding. However, cross-national research shows that those countries with more interventionist programs tend to produce more favourable indicators of family welfare and well-being (UNICEF, 2003). 


\section{References}

Baker, M. 1995. Canadian Family Policies: Cross-National Comparisons. Toronto: University of Toronto Press.

--- 2001. Families, Labour and Love: Family Diversity in a Changing World. Sydney: Allen and Unwin, and Vancouver: UBC Press.

--- 2006. Restructuring Family Policies: Convergences and Divergences. Toronto: University of Toronto Press.

Baker, M. \& Phipps, S. 1997. “Canada”, In Family Change and Family Policies in Great Britain, Canada, New Zealand and the United States. S.B. Kamerman \& A.J. Kahn (eds) . Oxford: Clarendon Press, pp. 103-205.

Baker, M. \& Tippin, D. 1999. Poverty, Social Assistance and the Employability of Mothers: Restructuring Welfare States. Toronto: University of Toronto Press.

Bala, N. \& Clarke, K.L. 1981. The Child and the Law Toronto: McGraw-Hill Ryerson.

Bashevkin, S. 1998. Women on the Defensive: Living Through Conservative Times. Toronto: University of Toronto Press.

Bolderson, H. \& Mabbett, D. 1991. Social Policy and Social Security in Australia, Britain and the USA. Aldershot, England: Avebury.

Bradbury, B. 1996. Income Support for Parents and Other Carers. Sydney: University of New South Wales, Social Policy Research Centre.

Bradshaw, J. \& Finch, N. 2002. A Comparison of Child Benefit Packages in 22 Countries. UK Department for Work and Pensions. Research Report \#174. Leeds: Corporate Document Services.

Brodie, J. 1996. “Restructuring and the New Citizenship”. In Rethinking Restructuring: Gender and Change in Canada. I. Bakker (ed).Toronto: University of Toronto Press, pp. 126-140.

Castles, Francis G. 1985. The Working Class and Welfare: Reflections on the Political Development of the Welfare State in Australia and New Zealand, 1890-1980. Sydney: Allen and Unwin.

Clark, J. 1995. Kinship Foster Care: An Overview of Research Findings and Policy-related Issues. Department of Human Development and Families Studies, Pennsylvania State University. 
Connolly, M. 2003. Kinship Care - A Selected Literature Review. Unpublished paper prepared for the Dept. of Child Youth and Family Services. Wellington: NZ.

Dalley, B. 1998. Family Matters: Child Welfare in Twentieth Century New Zealand. Auckland: Auckland University Press.

Esping-Andersen, G. 1990. The Three Worlds of Welfare Capitalism. Cambridge: Polity Press.

Gauthier, A.H. 1996. The State and the Family: A Comparative Analysis of Family Policies in Industrialized Countries. Oxford: Clarendon Press.

--- 2001. “Family Policies and Families’ Well-being: An International Comparison.” In Our Children’s Future: Child Care Policy in Canada. G. Cleveland and M. Krashinsky (eds). Toronto: University of Toronto Press, pp. 251-74.

Hantrais, L. 2004. Family Policy Matters: Responding to Family Change in Europe. Bristol: The Policy Press.

Heitlinger, Alena. 1993. Women's Equality, Demography and Public Policies. London: Macmillan.

Hobcraft, J. \& Kiernan, K. 2001. “Childhood Poverty, Early Motherhood and Adult Social Exclusion” British Journal of Sociology, Vol.52, No. 3, pp. 495-517.

Hunt, J. 2003. Family and Friends Carers. Report prepared for the UK Department of Health. http://www.doh.gov.uk/carers/familyandfriends.htm

Jaffe, P., Lemon, N. \& Poisson, S. 2003. Child Custody and Domestic Violence: A Call for Safety and Accountability. Thousand Oaks, London and New Delhi: Sage.

Jones, Michael. 1997. Reforming New Zealand Welfare. International Perspectives. Wellington, NZ: The Centre for Independent Studies.

Kaye, M. 1999. "The Hague Convention and the Flight from Domestic Violence: How Women are Being Returned by Coach and Four.” International Journal of Law, Policy and the Family, Vol. 13, No. 2, pp. 191-212.

Kingfisher, Catherine (ed.). 2002. Western Welfare in Decline: Globalization and Women's Poverty. Philadelphia: Pennsylvania State University Press.

Kelsey, Jane. 1995. Economic Fundamentalism. London: Pluto Press.

Krane, J. 2003. What's Mother Got to Do With It? Protecting Children from Sexual Abuse. Toronto: University of Toronto Press. 
Lipman, E.L.; Offord, D.R. \& Boyle, M.H. 1994. "Relation between Economic Disadvantage and Psychosocial Morbidity in Children.” Canadian Medical Association Journal, Vol. 151, No. 4, pp. 431-437.

McGilly, F. 1998. An Introduction to Canada’s Public Social Services: Understanding Income and Health Programs. $2^{\text {nd }}$ edition. Toronto: Oxford University Press.

McLaren, A. 1999. Twentieth-Century Sexuality. A History Oxford: Blackwell.

Matthews, K.M. \& Matthews, R. 1998. “Paradigms of Family, Welfare and Schooling in New Zealand” In The Family in Aotearoa New Zealand. V. Adair \& R. Dixon (eds). Auckland: Addison Wesley Longman.

Mishra, R. 1999. Globalization and the Welfare State. UK: Edward Elgar.

O’Connor, J.S.; Orloff, A.S. \& Shaver, S. 1999. States, Markets, Families: Gender Liberalism and Social Policy in Australia, Canada, Great Britain and the United States. Cambridge: Cambridge University Press.

OECD (Organisation for Economic Co-operation and Development). 2005. Society at a Glance: OECD Social Indicators Paris: OECD.

Radford, L. \& Hester, M. 2001. "Overcoming Mother Blaming? Future Directions for Research on Mothering and Domestic Violence”, In Domestic Violence in the Lives of Children. S. Graham-Bermann and J. Edleson (eds). Washington DC: American Psychological Association.

Roberts, H. 1997. “Children, Inequalities and Health.” British Medical Journal, Vol. 314, (April 12) (\#7087), p. 1122.

Smith, B. 1991. “Australian Women and Foster Care: A Feminist Perspective.” Child Welfare, Vol. 70, No. 2, pp. 175-84.

Statistics New Zealand. 2002. New Zealand Official Yearbook. Wellington: Statistics NZ.

Swift, K. 1995. Manufacturing 'Bad Mothers’? A Critical Perspective on Child Neglect Toronto: University of Toronto Press.

UNICEF (United Nations Children's Fund). 2000. A League Table of Child Poverty in Rich Nations. Florence: Innocenti Research Centre.

--- 2003. A League Table of Child Maltreatment Deaths in Rich Nations. Florence: Innocenti Research Centre.

--- $\quad$ 2005. Child Poverty in Rich Nations Florence: Innocenti Research Centre. 
--- 2007. Child Poverty in Perspective: An Overview of Child Well-Being in Rich Countries. Florence: Innocenti Research Centre.

Ursel, J. 1992. Private Lives, Public Policy: 100 Years of State Intervention in the Family. Toronto: Women's Press.

Yeates, N. 2001. Globalization and Social Policy. London: Sage Publications. 